\title{
PENGEMBANGAN MEDIA PEMBELAJARAN KALIMAT EFEKTIF PADA PELAJARAN BAHASA INDONESIA
}

\author{
Atika Mahryani Simamoral dan Mukhtar ${ }^{2}$ \\ SMA Negeri 1 Matauli Pandan ${ }^{1}$ dan Universitas Negeri Medan ${ }^{2}$ \\ atikamahryani@yahoo.com ${ }^{l}$
}

\begin{abstract}
Abstrak: Penelitian ini bertujuan untuk: (1) menghasilkan media pembelajaran interaktif yang layak digunakan, mudah dipelajari pebelajar dan dapat dipakai untuk pembelajaran individual, (2) untuk mengetahui keefektifan media pembelajaran interaktif yang dikembangkan pada pembelajaran Bahasa Indonesia. Jenis penelitian adalah penelitian dan pengembangan yang model Borg dan Gall yang dipadu dengan model pembelajaran Dick dan Carey. Hasil penelitian menunjukkan; (1) uji ahli materi pelajaran Bahasa Indonesia berada pada kualifikasi sangat baik (83,25\%), (2) uji ahli desain pembelajaran berada pada kualifikasi sangat baik (89,83\%), (3) uji ahli rekayasa perangkat lunak berada pada kualifikasi sangat baik (89,19\%), (4) uji coba perorangan berada pada kualifikasi sangat baik (91,55\%), (5) uji coba kelompok kecil berada pada kualifikasi sangat baik (90,72\%), (6) uji coba lapangan berada pada kualifikasi sangat baik (93,04\%). Hasil pengujian hipotesis membuktikan bahwa terdapat perbedaan yang signifikan antara hasil belajar siswa yang dibelajarkan dengan menggunakan media pembelajaran interaktif dengan hasil belajar siswa yang dibelajarkan dengan menggunakan media pembelajaran power point. Hal ini ditunjukkan dengan hasil pengolahan data diperoleh $t_{\text {hitung }}=11,61>t_{\text {tabel }}=1,69$, efektifitas penggunaan media pembelajaran interaktif $=87,70 \%$. Disimpulkan bahwa hasil belajar kelompok siswa yang dibelajarkan dengan menggunakan media game pembelajaran sebesar 87,70\% lebih tinggi dari kelompok siswa yang dibelajarkan dengan menggunakan media pembelajaran power point sebesar 69,90\%.
\end{abstract}

Kata Kunci: pengembangan media pembelajaran, kalimat efektif, bahasa Indonesia

Abstract: This study aims to: (1) generate media interactive learning proper use, easy to learn learners and can be used for individual learning, (2) to determine the effectiveness of interactive learning media developed in learning Indonesian. This type of research is the research and development of models Borg and Gall combined with Dick and Carey model of learning. The results showed; (1) Test Indonesian subject matter experts are at a very good qualifying $(83.25 \%)$, (2) test the instructional design experts are at a very good qualifying (89.83\%), (3) test software engineering experts are at excellent qualifications (89.19\%), (4) individual testing are at a very good qualifying (91.55\%), (5) testing small groups are at a very good qualifying (90.72\%), (6) field trials are in excellent qualifications (93.04\%). The test results prove the hypothesis that there are significant differences between student learning outcomes that learned to use the media interactive learning with student learning outcomes that learned by using learning media power point. This is indicated by the results of the processing of the data obtained $t=11.61>$ table $=1.69$, the effective use of interactive learning media $=87.70 \%$. The group concluded that the learning outcomes of students that learned by using learning games media for $87.70 \%$ higher than the group of students that learned by using learning media power point of $69.90 \%$.

Keywords: development of instructional media, effective sentences, Indonesian

\section{PENDAHULUAN}

Ketersediaan media yang biasa
digunakan di sekolah seperti buku teks,majalah,surat kabar dan papan tulis yang menimbulkan kebosanan dalam melakukan pembelajaran dalam kelas, sedangkan media audio dan visual seperti : televisi, radio, dan video serta media elektronik seperti komputer semua media yang digunakan tersebut belum dimanfaatkan dengan maksimal bahkan komputer hanya sebagai "penghias sekolah saja", karena tidak dipergunakan dengan 
maksimal dan rata-rata lab komputer digunakan hanya untuk mata pelajaran TIK saja. Oleh sebab itu, perlu adanya kreativitas pendidik dalam memanfaatkan media, bahkan sering dijumpai pendidik yang memanfaatkan media pembelajaran dengan memanfaatkan media pembelajaran apa yang ada di sekolah, misalnya buku teks saja.

Menilik dari hasil nilai bahasa Indonesia pada ujian nasional sebelumnya, nilai bahasa Indonesia sering sekali mengalami penurunan dibanding mata pelajaran lainnya. Fenomena ini mendeskripsikan jika bahasa Indonesia memiliki tingkat kesulitan yang sama atau mungkin lebih sulit dibanding matematika atau bahasa Inggris. Dalam skala yang lebih kecil hal tersebut juga sama terjadi pada siswasiswi kelas XI SMA Negeri 1 Matauli Pandan. Hal tersebut dapat dibuktikan dari hasil belajar siswa pada materi pembelajaran "kalimat efektif “. Masih banyak siswa yang belum tuntas atau memperoleh nilai kurang memuaskan dalam proses pembelajaran.

Hasil penelusuran dari wawancara yang penulis lakukan pada 60 guru di SMA Negeri 1 Matauli Pandan menunjukkan bahwa $86 \%$ dari guru-guru membutuhkan media pembelajaran interaktif dalam proses pembelajaran agar proses pembelajaran berjalan lebih efektif. Dari hasil wawancara dengan guru Bahasa Indonesia secara khusus menunjukkan bahwa pembelajaran Bahasa Indonesia selama ini dilakukan dengan cara ceramah dan menggunakan media dengan power point serta buku teks sebagai acuan pembelajaran. Mereka mengaku kesulitan memperoleh media pembelajaran yang efektif untuk pelajaran Bahasa Indonesiadi sekolah sehingga kegiatan pembelajaran kurang efektif dan peserta didik merasa kesulitan dalam memahami materi yang disampaikan. Dari wawancara yang penulis lakukan pada 50 orang siswa yang diambil sebagai sampel, $100 \%$ siswa menyatakan membutuhkan media pembelajaran interaktif yang dapat mereka jadikan sebagai sarana pembelajaran secara individual.

Visual Basic 2010 merupakan visual basic yang direkayasa untuk digunakan pada platform sehingga aplikasi yang dibuat dapat berjalan pada sistem komputer apa pun, oleh karena itu visual bassic 2010 dapat dijadikan sebagai media pembelajaran yang menarik dan interaktif karena di dalamnya terdapat teks, gambar, suara dan animasi.
Belajar adalah proses orang memperoleh berbagai kecakapan, keterampilan, dan sikap belajar (Geredler, 1991: 1). Pembelajaran merupakan sebuah upaya yang dilakukan untuk memperoleh kompetensipengetahuan, keterampilan, dan sikap yang diperlukan dalam melakukan suatu pekerjaan. Miarso (2009: 144) memaknai istilah pembelajaran sebagai aktivitas atau kegiatan yang berfokus pada kondisi dan kepentingan pebelajar (learner centered). Istilah pembelajaran digunakan untuk menggantikan istilah "pengajaran" yang lebih bersifat sebagai aktivitas yang berfokus pada guru (tecaher centered). Pembelajaran adalah proses yang sengaja dirancang untuk menciptakan terjadinya aktivitas belajar dalam diri individu. Dengan kata lain, pembelajaran merupakan sesuatu hal yang sengaja dirancang untuk mendukung terjadinya proses belajar internal dalam diri individu.

Surya (2003:7) menyatakan bahwa pembelajaran ialah suatu proses yang dilakukan oleh individu untuk memperoleh suatu perubahan perilaku yang baru secara keseluruhan, sebagai hasil dari pengalaman individu itu sendiri dalam interaksi dengan lingkungannya. Pendapat lainnya Rusman,dkk (2003:16) mengatakan bahwa pembelajaran merupakan proses interaksi komunikasi antara sumber belajar, guru dan siswa.

Menurut Sadiman (2011:6) memaknai pembelajaran sebagai kegiatan yang menekankan pada proses balajar maka usahausaha yang terencana dalam memanipulasi sumber-sumber belajara agar terjadi proses belajar dalam diri siswa

Bahasa Indonesia sebagai salah satu bahasa di dunia ini memiliki peranan penting dalam kehidupan bangsa Indonesia (Pamungkas, 2012: 1). Selanjutnya menurut Ibrahim (2002: 241) "proses pembelajaran bahasa Indonesia mengarahkan pebelajar untuk pengembangan keterampilan berbahasa yang menekankan pada kompetensi atau kemampuan dasar yang harus dimiliki oleh lulusan. Sedangkan menurut Taufina (2009: 114) "bahasa memiliki peran sentral dalam perkembangan intelektual, sosial, dan emosional siswa dan merupakan kunci penentu menuju keberhasilan dan mempelajari semua bidang studi".

Bahasa Indonesia digunakan dalam interaksi belajar mengajar. Dalam dunia 
pendidikan bahasa Indonesia adalah bahasa resmi yang harus dipergunakan. Hal ini mengandung makna yang sangat dalam bahwa bahasa Indonesia tidak bisa tergantikan oleh bahasa apapun selama penyelanggaraan pendidikan masih dilakukan di bumi Indonesia. (Pamungkas, 2012: 10). Bahasa merupakan alat komunikasi antarmanusia berupa bunyi simbol yang mengandung makna. Dengan bahasa, manusia dapat mengaktualisasikan pikiran dan perasaannya, serta dapat berinterakasi dengan sesamanya untuk berbagai keperluan hidup. Demikian pula bahasa Indonesia, sebagai sebuah bahasa, peran dan fungsinya tidak akan jauh berbeda dengan hal tersebut. Itulah sebabnya,

Bahasa Indonesia dikenal bahasa yang baik dan bahasa yang benar. Bahasa yang baik merupakan bahasa yang di pergunakan sesuai dengan situasi dan kondisi. Artinya dengan siapa seseorang berbicara, di mana, kapan, dan lain-lain menjadi dasar pijakan bahasa yang baik. Berbeda dengan bahasa yang baik, bahasa yang benar dipergunakan oleh masyarakat Indonesia dengan didasarkan pada patokan ejaan yang di sempurnakan. Hal ini mengandung pengertian bahwa bahasa yang benar adalah bahasa yang bersifat perspektif, artinya segala sesuatu didasarkan pada benar atau salahnya pengguanaan bahasa. (Pamungkas, 2012: 4).

Selanjutnya menurut Sugihastuti (dalam Kusumaningsih, 2013: 13) mengemukakan bahasa merupakan alat komunikasi yang efektif antar manusia. Dalam berbagai macam situasi , bahasa dapat dimanfaatkan untuk menyampaikan gagasan pembicara kepada pendengar atau penulis kepada pembaca.

Karateristik bahasa dapat dinyatakan sebagai sebuah sistem, artinya bahasa itu dibentuk oleh sejumlah komponen yang berpola secara tetap dan dapat dikaidahkan. Bahasa juga bersifat sistemis karena tersusun menurut sutau pola tertentu, tidak tersusun secara acak atau sembarangan. Oleh karena itu, lazim disebut bahasa itu bersifat unik meskipun juga bersifat universal (Kusumaningsih, 2013: 14). Pembelajaran bahasa Indonesia diarahkan untuk meningkatkan kemampuan siswa untuk berkomunikasi dalam bahasa Indonesia dengan baik dan benar, baik secara lisan maupun tulis, serta menumbuhkan aspresiasi terhadap hasil karya kesastraan manusia Indonesia.
Kalimat eferktif adalah kalimat yang memiliki kemampuan untuk menimbulkan kembali gagasan-gagasan pada pikiran pembaca atau penulis (Kusumaningsih 2013: 57). Selanjutnya Andayani (2009: 67) menjelaskan pengertian kalimat efektif sebagai berikut : (1) Kalimat efektif adalah kalimat yang benar dan jelas dan dengan mudah dipahami orang lain. (2) Disusun secara sadar untuk mencapai daya informasi yang diinginkan penulis terhadap pembacanya.(3) Pembaca memahami apa yang disampaikan. (4) Kalimat yang tepat mewakili gagasan atau perasaan penyampai pesan dan sanggup memberikan gambaran yang sama tepatnya pada pembaca atau pendengar. (5) Kalimat yang disusun dengan sadar dan sengaja untuk mencapai daya informasi yang tepat dan baik. (6) Jenis kalimat yang dapat memberikan efek tertentu dalam komunikasi. Efek yang dimaksudkan di sini adalah kejelasan informasi. (7) Kalimat efektif tidak menggunakan katakata mubazir, tetapi juga tidak kekurangan kata. (8) Kalimat efektif menggunakan pengertian yang logis sejalan dengan nalar yang tepat"Sedangkan E. Kosasih (2002) menyatakan, kalimat efektif adalah kalimat yang memenuhi syarat-syarat : (1) Secara tepat mewakili gagasan pembicara atau penulisnya; (2) Menimbulkan gagasan yang sama tepatnya antara pikiran pendengar atau pembaca seperti yang dipikirkan oleh pembicara atau penulisnya.

Kata media didefinisikan dengan multi makna baik dilihat secara terbatas maupun secara luas. Munculnya berbagai macam definisi disebabkan adanya perbedaan dalam sudut pandang, maksud, dan tujuannya. Heinich (1996: 5) Media merupakan komunikasi berarti seperti film, televisi, radio, audio, rekaman, foto, diproyeksikan dan sejenisnya adalah media komunikasi. Semuanya itu dianggap media pembelajaran ketika digunakan untuk menyampaikan pesan dalam pembelajaran

AECT (Association forEducation and Communication Technology , 1977:201) memaknai media sebagai segala bentuk yang dimanfaatkan dalam proses penyaluran informasi. NEA(National Education Association) memaknai media sebagai segala benda yang dapat dimanipulasi, dilihat, didengar, dibaca, atau dibincangkan beserta instrumen yang digunakan untuk kegiatan tersebut. 
Sadiman, dkk (2003: 6) mengemukakan pendapat tentang media adalah Berbagai jenis komponen dalam lingkungan, siswa yang dapat merangsangnya untuk belajar. Menurut Smaldino (2008: 7) juga mengemukakan lima tipe dasar media, yaitu (1) teks, yang dapat disajikan dalam berbagai format seperti buku,poster, papan tulis, layar komputer, dan sebagainya, (2) audio, termasuk di dalamnya segala sesuatu yang dapat didengar seperti suara manusia, musik, (suara deru mesin),suara berisik, dan sebagainya, (3) visual, termasuk diagram dalam poster, gambar di papan tulis, foto,grafik di buku, kartun, dan sebagainya, (4) Video, yaitu media yang menampilkan gerakan termasuk DVD, rekaman video, animasi komputer, dan sebagainya (5) perekayasa, yaitu bersifat tiga dimensi dan bisa disentuh dan dipegang oleh siswa (6) Orang-orang, berupa guru, siswa dan ahli bidang studi.

$$
\text { Dalam merencanakan dan }
$$

melaksanakan aktivitas pembelajaran, setiap guru dituntut dapat mempersiapkan dan memfungsikan segala unsur yang menunjang kelancaran proses pembelajaran agar dapat berjalan dengan efektif dan efisien. Sebagai salah satu unsur dalam menunjang pembelajaran, guru dituntut agar rmengetahui dan merancang pemakaian media pembelajaran serta dapat mengetahui fungsi dan kegunaan media tersebut. Menurut Sadiman (2003:17) fungsi atau kegunaan media antara lain: (1) memperjelas penyajian pesan agar tidak terlalu bersifat vervalistik, (2) mengatasi keterbatasan ruang waktu dan daya indra, (3) dapat mengatasi sikap pasif pada anak, (4) dengan sifat yang unik pada setiap siswa ditambah lagi dengan lingkungan dan pengalaman yang berbeda dapat diatasi dengan media

Dalam memilih media yang paling tepat, Dick dan Carey (2005) juga mengemukakan beberapa faktor penting dalam pemilihan media pembelajaran, yaitu (1) ketersediaan media di lingkungan pernbelajaran, (2) kesanggupan ahli memproduksi materi pembelajaran untuk digunakan dengan media yang dipilih, (3) fleksibilitas, waktu,dan kecocokan materi dengan media, dan (a) faktor biaya. Disamping kesesuaian dengan perilaku belajarnya, faktor lain yang harus dipertimbangkan dalam pemilihan media yaitu faktor yang menyangkut keluwesan, kepraktisan dan ketahanan media yang bersangkutan untuk waktu yang lama.
Selain itu faktor efektifitas harus tetap diperhatikan sebab faktor efektifitas ini berpengaruh terhadap biaya pemakaian dalam jangka waktu yang panjang

Media pembelajaran merupakan bagian yang saling terikat dengan metode, Strategi dalam sistem pembelajaran. Hal ini sependapat oleh Sumiati (2008: 159) mengatakan bahwa media pembelajaran merupakan bagian integral dalam sistem pembelajaran. Sejalan dengan itu Hamid (2009: 55) mengemukakan bahwa media pembelajaran adalah komponen strategi penyampaian yang dapat dimuati pesan yang akan disampaikan kepada pebelajar, apakah itu orang, alat atau bahan. Sumiati (2008: 160) mengemukakan bahwa media merupakan segala sesuatu yang dapat digunakan untuk menyalurkan pesan (message), merangsang pikiran, perasaan, perhatian dan kemauan siswa sehingga terdorong proses belajar.

Ada dua pendekatan yang dilakukan dalam pemanfaatan rnedia pembelajaran menurut Sumiati (2008:162) (1) media by design yaitu media pembelajaran yang dirancang, dipersiapkan, dan dibuat sendiri oleh guru lalu digunakan dalam proses pembelajaran, Pendekatan ini sudah tentu membutuhkan banyak biaya untuk membelinya, lagi pula belum tentu media itu cocok untuk penyampaian bahan pelajaran dan dengan kegiatan belajaryang dilakukan siswa (2) media by utulization yaitu media pembelajaran yang dibuat oleh orang lain atau suatu lembaga/instritusi, sedangkan guru hanya tinggal menggunakan atau memanfaatkannya

Rudi Brets (dalam Sumiati 2008:162) mengklasifikasikan media menjadi 3 ciri yaitu suara (audio), bentuk (visual) dan gerak (motion). Sehingga dapat dikatakan bahwa dalam media pembelajaran yang baik harus memiliki salah satu dari ketiga karakteristik media pembelajaran.

Penggunaan media pembelajaran pada tahap orientasi pembelajaran sangat membantu keefeklifitasan proses pembelajaran dan penyampaian pesan isi pembelajaran pada saat ini. Di samping membangkitkan motivasi dan minat siswa, media pembelajaran juga dapat membantu siswa meningkatkan pemahaman,penyajian data dengan menarik dan terpercaya, memudahkan penafsinan data, dan pemadatan informasi. Sejalan menurut Sumiati (2003:163) mengemukakan manfaat dari penggunaan media pembelajaran di sekolah 
yaitu: (1) Menjelaskan materi pembelajaran objek yang abstrak (tidak nyata) menjadi konkrit (nyata), (2) memberikan pengalaman langsung karena siswa dapat berkomunikasi dan berinteraksi dengan lingkungan tempat belajarnya, (3) Mempelajari materi pembelajaran secara berulang-ulang, (4) memungkinkan adanya persamaan pendapat dan persepsi yang benar terhadap suatu materi pembelajaran atau objek, (4) menarik perhatian siswa, (5) Membantu siswa belajar secara individual, kelompok dan klasikal, (6) materi pembelajaran lebih lama diingat dan mudah untuk diungkapkan kembali dengan cepat dan tepat, (7) mempermudah dan mempercepat guru menyajikan materi pembelajaran dalam proses pembelajaran, sehingga memudahkan siswa untuk mengerti dan memahami, (8) mengatasi keterbatasan ruang, waktu dan indra.

Media interaktif digolongkan sebagai media konstruktifistik yang terdiri dari pembelajaran, siswa, dan proses pernbelajaran. Dalam proses pembelajaran teknologi seperti komputer, adalah alat dalam multimedia dan jaringan web terluas di dunia yang sangat besar pengaruhnya terhadap siswa dalam proses pembelajaran. Program multimedia interaksi merupakan salah satu media pembelajaran yang berbasis komputer yang mensinergikan semua media yang terdiri dari teks, grafik, foto, video, animasi, musik, narasi menurut Warsita (2008:36)

Pengertian interaktif menurut Warsita (2008:156) terkait dengan komunikasi dua arah. Komponen komunikasi dalam multimedia interaktif (berbasis komputer) adalah hubungan antara manusia (sebagaiuser/pengguna produk) dan komputer (software/ aplikasi/produk dalam format filetertentu biasanya dalam bentuk CD). Dengan demikian produk/CD/aplikasi yang diharapkan memiliki hubungan dua arah/ timbal balik antara software/ aplikasi dengan usernya. Interaktifitas dalam multimedia diberikan batasan sebagai berikut (1) pengguna (user) dilibatkan untuk berinteraksi dengan program aplikasi, (2) aplikasi informasi interaktif bertujuan agar pengguna bisa mendapatkan hanya informasi yang diinginkan saja tanpa harus melahap semuanya.

$$
\text { Menurut Cheng (2009:204) }
$$

mengatakan bahwa multimedia interaktif ini dirancang untuk menawarkan untuk mahasiswa tahun terakhir. Konten multimedia pembelajaran yang interaktif dalam bentuk 3D, grafik, suara, video, animasi dan menciptakan interaksi. Sedangkan menurut Heinich (1997:187) mengemukakan kumpulan materi pembelajaran yang menyertakan lebih dari satu jenis media yang disusun dalam satu topik yang di dalamnya terdapat film strip, slide, videotape, rekaman, gambar, OHP, film pendek, peta, lembar kerja, grafik, bagan, brosur, objek nyata dan model.

Karakteristik terpenting pada media pembelajaran interaktif adalah bahwa siswa tidak hanya memperhatikan penyajian atau objek, tetapi dipaksa untuk berinteraksi selama mengikuti pelajaran. Menurut Miarso (2009:465) paling sedikit ada tiga macam interaksi yang dapat diidentifikasi. Pada tingkat pertama siswa dengan sebuah program, misalnya mengisi blanko pada teks yang terprogram. Tingkat berikutnya siswa berinteraksi dengan mesin, misalnya mesin pembelajaran, simulator, laboratorium bahasa atau terminal komputer. Bentuk ketiga media interaktif adalah yang mengatur interaksi antar siswa secara teratur tetapi tidak terprogram.

Visual studio .NET merupakan sebuah integrated Development Envirotment (IDE) atau lingkungan kerja yang digunakan untuk membangun aplikasi .NET dengan mudah (Andi, 2012: 7). Microsoft Visual Basic 2010 Profesional adalah alat penting untuk individu melakukan tugas-tugas pembangunan dasar. Ini menyederhanakan penciptaan, debugging, dan penyebaran aplikasi pada berbagai platform, termasuk SharePoint dan Cloud. Visual Basic 2010 Profesional dilengkapi dengan dukungan terpadu untuk pengembangan uji-didorong, serta alat debugging yang membantu memastikan solusi berkualitas tinggi. Menulis kode aplikasi sering membutuhkan banyak memiliki desainer dan editor terbuka sekali.

Menurut Zaman, dkk (2012:3) mengemukakan bahwa karakteristik media pembelajaran interaktif adalah :1) curriculum,desain pembelajaran harus sesuai dengan kurikulum pendidikan yang sudah ditetapkan. Aspek desain kurikulum dan pembelajaran terdiri dari 6 penilaian yaitu (1) kesesuaian sasaran, (2) kelengkapan unsur pembelajaran,(3) kejelasan tujuan, konsistensi tujuan-materi-evaluasi,(5) pemberian contoh dan (6) aspek-aspek pedagogik. 2) content, penilaian content pada media interaktif didasarkan beberapa aspek, yakni (1) kebenaran substansi materi, (2) 
kecukupan cakupan , (3) kedalam, (4) aktualitas, (5)kelengkapan sumber. 3) communication, (1) aspek kejelasan pesan,menumbuhkan motivasi 4) computer capasity, kemampuan komputer multimedia 5) creativity, tidak melanggar etika 6) compability, dapat diterima secara umum, dan mudah digunakan 7) cosmetic, tampilan desain yang menarik dan 8) interaktivity memunculkan produk yang interaktif.

Dalam pengembangan media pembelajaran interaktif pada mata pelajaran bahasa Indonesiadigunakan model pengembangan produk Borg dan Gall (2005), dan untuk mengembangkan recana pembelajarannya dipadukan dengan model pengembangan pembelajaran

Masalah dalam penelitian ini adalah: (1) Apakah kualitas media pembelajaran yang dikembangkan dengan menggunakan media interaktif pada pembelajaran Bahasa Indonesia?; dan (2) Apakah efektifitas media pembelajaran interaktif yang dikembangkan pada pembelajaran Bahasa Indonesia?

\section{METODE}

Penelitian dilakukan di SMA Negeri 1 Matuli Pandan yang terletak di Jalan Ki Hajar Dewantara No. 1 Pandan Kabupaten Tapanuli Tengah pada siswa kelas XI. Penelitian ini Model pengembangan yang digunakan dalam media pembelajaran interaktif ini adalah model pengembangan Borg and Gall (1983) yang dikombinasikan dengan model pengembangan pembelajaran model Dick dan Carey (2005). Adapun langkah-langkah tahapan pengembangannya adalah sebagai berikut :

1. Melakukan penelitian pendahuluan yang meliputi:

a. Identifikasi kebutuhan pembelajaran dan menentukan standar kompetensi mata pelajaran.

b. Melakukan analisis pembelajaran.

c. Mangidentifikasi karakteritik dan perilaku awal peserta didik.

d. Menulis kompetensi dasar dan indikatornya.

e. Menulis tes acuan patokan.

f. Menyusun strategi pembelajaran yang terdiri dari:
a) Penjelasan tentang instruksional
b) Penjelasan relevansi isi pelajaran baru

c) Penjelasan tentang materi pelajaran atau konsep, prinsip, dan prosedur yang akan dipelajari peserta didik

d) Tes formatif dan umpan balik

e) Tindak lanjut

g. Mengembangkan

bahan pembelajaran.

2. Pembuatan desain software, yang meliputi
a. Pembuatan naskah
b. Pembuatan storyboard
c. Pembuatan Flowchart View

3. Pengumpulan bahan, yang meliputi:

a. Pembuatan dan pengumpulan gambar (image) dan animasi.

b. Perekaman dan pengumpulan audio

4. Mengembangkan dan membuat media pembelajaran interaktif

5. Review dan uji coba produk.

6. Uji keefektifan produk

Analisis data dalam penelitian ini menggunakan analisis deskriptif kuantitatif. Semua data yang terkumpul dianalisis dengan teknik statistik deskriptif yang secara kuantitatif dipisahkan menurut kategori untuk mempertajam penilaian dalam menarik kesimpulan. Data kualitatif yang berupa pernyataan sangat kurang baik, kurang baik, sedang, baik dan sangat baik diubah menjadi data kuantitatif dengan skala nilai 1 sampai 5 . Hasilnya dirata-rata dan digunakan untuk menilai kualitas software pembelajaran. Kriteria software akan dikonversikan menjadi nilai dengan skala lima menggunakan Skala Likert yang dianalisis secara deskriptif persentase dengan rumus sebagai berikut (Purwanto, 2009:112)

$X=\frac{R}{N} \times 100 \%$

Dimana :

$X \quad$ : Nilai yang diharapkan (Dicari)

$\mathrm{R} \quad$ : Jumlah skor dari item atau soal yang dijawab benar

$\mathrm{N} \quad$ : Skor maksimum dari tes tersebut

Dengan kriteria penilaian seperti yang tertulis pada tabel 5 berikut ini.

Tabel 1. Kriteria penilaian

\begin{tabular}{|c|c|c|}
\hline Nilai & Kriteria & Persentase \\
\hline A & Sangat baik & $80 \% \leq X \leq 100 \%$ \\
\hline B & Baik & $60 \% \leq X<80 \%$ \\
\hline
\end{tabular}




\begin{tabular}{|c|c|c|}
\hline C & Sedang & $40 \% \leq X<60 \%$ \\
\hline $\mathrm{D}$ & Kurang baik & $20 \% \leq X<40 \%$ \\
\hline $\mathrm{E}$ & $\begin{array}{c}\text { Sangat } \\
\text { kurang baik }\end{array}$ & $0 \% \leq X<20 \%$ \\
\hline
\end{tabular}

$\mathrm{X}=$ Skor Empiris (Purwanto, 2009:82)

Analisis data pada penelitian ini menggunakan tehnik analisis kuantitatif. Sebelum dilakukan uji hipotesis, terlebih dahulu dilakukan uji persyaratan yaitu uji normalitas dan uji homogenitas. Uji normalitas dilakukan untuk mengetahui apakah skor variabel yang diteliti berasal dari populasi yang berdistribusi normal. Untuk mengetahui ini dilakukan dengan menggunakan uji Lilliefors.

Untuk menguji homogenitas data, digunakan uji kesamaan dua varians. Dilakukan uji dua pihak dengan taraf signifikansi 0,05 , hipotesis di atas diuji dengan statistika:

2008:199)

$$
\mathrm{F}=\frac{\text { Varians terbesar }}{\text { Varians terkecil }}
$$

(Sugiyono,

Kriteris pengujian hipotesis:

Ho diterima jika $\mathrm{F} \leq \mathrm{F}(\mathrm{V} 1, \mathrm{~V} 2)$ dan $\mathrm{Ho}$ ditolak jika $\mathrm{F} \geq \mathrm{F}(\mathrm{V} 1, \mathrm{~V} 2)$

Untuk melihat apakah ada perbedaan yang signifikan antara hasil belajar dengan penggunaan media pembelajaran interaktif dan Power point maka dilakukan uji hipotesis dengan uji t.

Untuk melihat keefektifan media pembelajaran interaktif yang dieksperimenkan digunakan rumus perhitungan efektifitas berikut (Purwanto; 2004:112):

$$
X=\frac{R}{N} \times 100 \%
$$

Dimana :

$\mathrm{S} \quad$ : Nilai yang diharapkan (dicari)

$\mathrm{R} \quad$ : Jumlah skor dari item atau soal yang dijawab benar

$\mathrm{N} \quad$ : Skor maksimum dari tes tersebut

Adapun rumusan hipotesis statistik ini dinyatakan sbb :

Hipotesis : $\mathrm{H}_{\mathrm{O}}: \mu 1=\mu 2$

\section{Keterangan :}

$$
\mathrm{H}_{\mathrm{a}}: \mu 1>\mu 2
$$

$\mu 1$ : Rata-rata hasil belajar bahasa Indonesia siswa yang diajar dengan menggunakan media pembelajaran interaktif

$\mu 2$ : Rata-rata hasil belajar bahasa Indonesia siswa yang diajar dengan menggunakan media pembelajaran power point.

\section{HASIL DAN PEMBAHASAN}

Hasil

Berdasarkan indikator penilaian produk yang dikembangkan terhadap beberapa ahli menunjukkan bahwa:

(1) Penilaian Media Pembelajaran Interaktif Oleh Ahli Materi Tentang Kualitas Materi Pembelajaran rata-rata skor 8,37 atau $83,75 \%$ kriteria sangat baik;

(2) Penilaian Media Pembelajaran Interaktif Oleh Ahli Materi Tentang Kualitas Strategi Pembelajaran rata-rata skor 8,6 atau $86 \%$ kriteria sangat baik;

(3) Penilaian Media Pembelajaran Interaktif Oleh Ahli Materi Tentang Sistem Penyampaian Pembelajaran (Skala 1-5) rata-rata skor 8 atau $80 \%$ kriteria baik;

(4) Penilaian Media Pembelajaran Interaktif Oleh Ahli Desain Pembelajaran Tentang Aspek Kualitas Desain Informasi pada Aspek Kelayakan Isi rata-rata skor 9,25 atau 92,5\% kriteria sangat baik;

(5) Penilaian Media Pembelajaran Interaktif Oleh Ahli Desain Pembelajaran Tentang Kualitas Desain Informasi Pada Aspek Penyajian rata-rata skor 10 atau $100 \%$ kriteria sangat baik;

(6) Penilaian Media Pembelajaran Interaktif Oleh Ahli Desain Pembelajaran Tentang Aspek Kualitas Desain Interaksi rata-rata skor 8,67 atau 86,67\% kriteria sangat baik;

(7) Penilaian Media Pembelajaran Interaktif Oleh Ahli Desain Pembelajaran Tentang Aspek Kualitas Presentasi rata-rata skor 9,33 atau 93,33\% kriteria sangat baik;

(8) Penilaian Media Pembelajaran Interaktif Oleh Ahli Desain Pembelajaran Tentang Kualitas Desain Informasi Pada Aspek Kegrafikan rata-rata skor 9 atau $90 \%$ kriteria sangat baik;

(9) Penilaian Media Pembelajaran Interaktif Oleh Ahli Rekayasa Perangkat Lunak Pada Aspek Pemograman rata-rata skor 9,13 atau 91,23\% kriteria sangat baik;

(10) Penilaian Media Pembelajaran Interaktif Oleh Ahli Rekayasa Perangkat Lunak Pada Aspek Kualitas Teknis/Tampilan rata-rata skor 8.71 atau $87,14 \%$ kriteria sangat baik

Hasil uji coba berupa skor penilaian terhadap media pembelajaran interaktif pada pembelajaran Bahasa Indonesia pada uji coba perorangan dapat dilihat pada Tabel 2 . 
Tabel 2. Skor Penilaian Media Pembelajaran Interaktif pada Pembelajaran Bahasa Indonesia Pada Uji Coba Perorangan Tentang Kualitas Materi Pembelajaran

\begin{tabular}{|c|c|c|c|c|c|c|c|}
\hline \multirow{2}{*}{ No } & \multirow{2}{*}{ Indikator Penilaian } & \multicolumn{3}{|c|}{ Responden } & \multirow{2}{*}{$\begin{array}{l}\text { Jumlah } \\
\text { Skor }\end{array}$} & \multirow{2}{*}{ Rata-rata } & \multirow{2}{*}{ Kriteria } \\
\hline & & 1 & 2 & 3 & & & \\
\hline 1 & Kesesuaian materi & 4 & 4 & 4 & 12 & $80,00 \%$ & Baik \\
\hline 2 & Kejelasan petunjuk belajar & 5 & 5 & 4 & 14 & $93,33 \%$ & Sangat Baik \\
\hline 3 & $\begin{array}{l}\text { Kemudahan memahami kalimat } \\
\text { pada teks }\end{array}$ & 5 & 4 & 5 & 14 & $93,33 \%$ & Sangat Baik \\
\hline 4 & $\begin{array}{l}\text { Kemudahan memahami } \\
\text { pembelajaran }\end{array}$ & 5 & 5 & 5 & 15 & $100,00 \%$ & Sangat Baik \\
\hline 5 & Ketepatan urutan penyajian & 5 & 5 & 4 & 14 & $93,33 \%$ & Sangat Baik \\
\hline 6 & Kecukupan latihan & 4 & 5 & 4 & 13 & $86,67 \%$ & Sangat Baik \\
\hline 7 & Kejelasan umpan balik & 5 & 5 & 5 & 15 & $100,00 \%$ & Sangat Baik \\
\hline 8 & Bantuan belajar dengan program & 4 & 4 & 5 & 13 & $86,67 \%$ & Sangat Baik \\
\hline \multicolumn{5}{|c|}{ Jumlah } & 110 & - & - \\
\hline
\end{tabular}

Penilaian siswa pada media pembelajaran interaktif tentang aspek kualitas teknis/tampilan dapat dilihat pada Tabel 3.

Tabel 3. Skor Penilaian Media Pembelajaran Interaktif pada Pembelajaran Bahasa Indonesia Pada Uji Coba Perorangan Tentang Aspek Kualitas Teknis/Tampilan

\begin{tabular}{|c|c|c|c|c|c|c|c|}
\hline \multirow{2}{*}{ No } & \multirow{2}{*}{ Indikator Penilaian } & \multicolumn{3}{|c|}{ Responden } & \multirow{2}{*}{$\begin{array}{c}\text { Jumlah } \\
\text { Skor }\end{array}$} & \multirow{2}{*}{ Rata-rata } & \multirow{2}{*}{ Kriteria } \\
\hline & & 1 & 2 & 3 & & & \\
\hline 1 & Keindahan Tampilan layar & 5 & 4 & 4 & 13 & $86,67 \%$ & Sangat Baik \\
\hline 2 & Keterbacaan teks & 5 & 5 & 5 & 15 & $100,00 \%$ & Sangat Baik \\
\hline 3 & Kualitas gambar & 4 & 4 & 4 & 12 & $80,00 \%$ & Baik \\
\hline 4 & Komposisi warna & 4 & 4 & 4 & 12 & $80,00 \%$ & Baik \\
\hline 5 & Navigasi & 5 & 5 & 5 & 15 & $100,00 \%$ & Sangat Baik \\
\hline 6 & Penggunaan animasi & 4 & 5 & 5 & 14 & $93,33 \%$ & Sangat Baik \\
\hline 7 & Interaksi & 5 & 5 & 5 & 15 & $100,00 \%$ & Sangat Baik \\
\hline \multicolumn{5}{|c|}{ Jumlah } & 96 & - & - \\
\hline \multicolumn{5}{|c|}{ Rata-rata } & 13,71 & $91,43 \%$ & Sangat Baik \\
\hline
\end{tabular}

\section{Data Hasil Uji Coba Tahap III Uji Coba Kelompok Kecil}

Tabel 4. Skor Penilaian Media Pembelajaran Interaktif pada Pembelajaran Bahasa Indonesia Uji Coba Kelompok Kecil Aspek Kualitas Materi Pembelajaran

\begin{tabular}{|c|c|c|c|c|c|c|c|c|c|}
\hline \multirow{2}{*}{ No } & \multirow{2}{*}{ Indikator Penilaian } & \multicolumn{5}{|c|}{ Skor } & \multirow[b]{2}{*}{ Jumlah } & \multirow[b]{2}{*}{ Rata-rata } & \multirow{2}{*}{ Kriteria } \\
\hline & & 1 & 2 & 3 & 4 & 5 & & & \\
\hline 1 & Kesesuaian materi & & & & 4 & 5 & 41 & $91,11 \%$ & Sangat Baik \\
\hline 2 & $\begin{array}{l}\text { Kejelasan petunjuk } \\
\text { belajar }\end{array}$ & & & & 3 & 6 & 42 & $93,33 \%$ & Sangat Baik \\
\hline 3 & $\begin{array}{l}\text { Kemudahan memahami } \\
\text { kalimat pada teks }\end{array}$ & & & & 4 & 5 & 41 & $91,11 \%$ & Sangat Baik \\
\hline 4 & $\begin{array}{l}\text { Kemudahan memahami } \\
\text { pembelajaran }\end{array}$ & & & & 4 & 5 & 41 & $91,11 \%$ & Sangat Baik \\
\hline 5 & $\begin{array}{l}\text { Ketepatan urutan } \\
\text { penyajian }\end{array}$ & & & & 3 & 6 & 42 & $93,33 \%$ & Sangat Baik \\
\hline 6 & Kecukupan latihan & & & & 3 & 6 & 42 & $93,33 \%$ & Sangat Baik \\
\hline 7 & Kejelasan umpan balik & & & & 6 & 3 & 39 & $86,67 \%$ & Sangat Baik \\
\hline 8 & $\begin{array}{l}\text { Bantuan belajar dengan } \\
\text { program }\end{array}$ & & & & 1 & 8 & 44 & $97,78 \%$ & Sangat Baik \\
\hline
\end{tabular}




\begin{tabular}{|c|c|c|c|c|c|c|c|c|c|}
\hline \multirow{2}{*}{ No } & \multirow{2}{*}{ Indikator Penilaian } & \multicolumn{5}{|c|}{ Skor } & \multirow{2}{*}{ Jumlah } & Rata-rata & Kriteria \\
\cline { 2 - 5 } & & 1 & 2 & 3 & 4 & 5 & & - & - \\
\hline Jumlah & & & 332 & $\mathbf{4 1 , 5}$ & $\mathbf{9 2 , 2 2 \%}$ & Sangat Baik \\
\hline
\end{tabular}

Tabel 5. Skor Penilaian Media Pembelajaran Interaktif pada Pembelajaran Bahasa Indonesia Uji Coba Kelompok Kecil Aspek Kualitas Teknis/Tampilan

\begin{tabular}{|c|c|c|c|c|c|c|c|c|c|}
\hline \multirow{3}{*}{ No } & \multirow{3}{*}{ Indikator Penilaian } & \multirow{2}{*}{\multicolumn{5}{|c|}{ Skor }} & \multirow{3}{*}{ Jumlah } & \multirow{3}{*}{ Rata-rata } & \multirow{3}{*}{ Kriteria } \\
\hline & & & & & & & & & \\
\hline & & 1 & 2 & 3 & 4 & 5 & & & \\
\hline 1 & $\begin{array}{l}\text { Keindahan tampilan } \\
\text { layar }\end{array}$ & & & & 3 & 6 & 42 & $93,33 \%$ & Sangat Baik \\
\hline 2 & Keterbacaan teks & & & & 9 & & 36 & $80,00 \%$ & Baik \\
\hline 3 & Kualitas gambar & & & & 4 & 5 & 41 & $91,11 \%$ & Sangat Baik \\
\hline 4 & Komposisi warna & & & & 5 & 4 & 40 & $88,89 \%$ & Sangat Baik \\
\hline 5 & Navigasi & & & & 4 & 5 & 41 & $91,11 \%$ & Sangat Baik \\
\hline 6 & Penggunaan animasi & & & & 5 & 4 & 40 & $88,89 \%$ & Sangat Baik \\
\hline 7 & Interaksi & & & & 4 & 5 & 41 & $91,11 \%$ & Sangat Baik \\
\hline \multicolumn{7}{|c|}{ Jumlah } & 281 & - & - \\
\hline \multicolumn{7}{|c|}{ Rata-rata } & 40,14 & $89,21 \%$ & Sangat Baik \\
\hline
\end{tabular}

\section{Data Hasil Uji Coba Tahap IV Uji Coba Lapangan}

Tabel 6. Skor Penilaian Media Pembelajaran Interaktif Pada Pembelajaran Bahasa Indonesia Uji Coba Lapangan Aspek Kualitas Materi Pembelajaran

\begin{tabular}{|c|c|c|c|c|c|c|c|c|c|}
\hline \multirow{2}{*}{ No } & \multirow{2}{*}{ Indikator Penilaian } & \multicolumn{5}{|c|}{ Skor } & \multirow{2}{*}{ Jumlah } & \multirow{2}{*}{ Rata-rata } & \multirow{2}{*}{ Kriteria } \\
\hline & & 1 & 2 & 3 & 4 & 5 & & & \\
\hline 1 & Kesesuaian materi & & & & 16 & 11 & 119 & $88,15 \%$ & Sangat Baik \\
\hline 2 & $\begin{array}{l}\text { Kejelasan petunjuk } \\
\text { belajar }\end{array}$ & & & & 14 & 13 & 121 & $89,63 \%$ & Sangat Baik \\
\hline 3 & $\begin{array}{l}\text { Kemudahan } \\
\text { memahami kalimat } \\
\text { pada teks }\end{array}$ & & & & 14 & 13 & 121 & $89,63 \%$ & Sangat Baik \\
\hline 4 & $\begin{array}{l}\text { Kemudahan } \\
\text { memahami } \\
\text { pembelajaran }\end{array}$ & & & & 15 & 12 & 120 & $88,89 \%$ & Sangat Baik \\
\hline 5 & $\begin{array}{l}\text { Ketepatan urutan } \\
\text { penyajian }\end{array}$ & & & & 14 & 13 & 121 & $89,63 \%$ & Sangat Baik \\
\hline 6 & Kecukupan latihan & & & & 17 & 10 & 118 & $87,41 \%$ & Sangat Baik \\
\hline 7 & $\begin{array}{l}\text { Kejelasan umpan } \\
\text { balik }\end{array}$ & & & & 15 & 12 & 120 & $88,89 \%$ & Sangat Baik \\
\hline 8 & $\begin{array}{l}\text { Bantuan belajar } \\
\text { dengan program }\end{array}$ & & & & 20 & 7 & 115 & $85,19 \%$ & Sangat Baik \\
\hline \multicolumn{7}{|c|}{ Jumlah } & 955 & - & - \\
\hline \multicolumn{7}{|c|}{ Rata-rata } & & $88,43 \%$ & Sangat Baik \\
\hline
\end{tabular}

Tabel 7. Skor Penilaian Media Pembelajaran Interaktif Pada Pembelajaran Bahasa Indonesia Uji Coba Lapangan Aspek Kualitas Teknis/ Tampilan

\begin{tabular}{|c|c|c|c|c|c|c|c|c|c|}
\hline \multirow{2}{*}{ No } & \multirow{2}{*}{ Indikator Penilaian } & \multicolumn{5}{|c|}{ Skor } & \multirow{2}{*}{ Jumlah } & \multirow{2}{*}{ Rata-rata } & \multirow{2}{*}{ Kriteria } \\
\hline & & 1 & 2 & 3 & 4 & 5 & & & \\
\hline 1 & $\begin{array}{l}\text { Keindahan tampilan } \\
\text { layar }\end{array}$ & & & & 13 & 14 & 122 & $90,37 \%$ & Sangat Baik \\
\hline 2 & Keterbacaan teks & & & & 17 & 10 & 118 & $87,41 \%$ & Sangat Baik \\
\hline 3 & Kualitas gambar & & & & 13 & 14 & 122 & $90,37 \%$ & Sangat Baik \\
\hline 4 & Komposisi warna & & & & 10 & 17 & 125 & $92,59 \%$ & Sangat Baik \\
\hline
\end{tabular}




\begin{tabular}{|c|c|c|c|c|c|c|c|c|c|}
\hline \multirow[b]{2}{*}{ No } & \multirow[b]{2}{*}{ Indikator Penilaian } & \multicolumn{5}{|c|}{ Skor } & \multirow[b]{2}{*}{ Jumlah } & \multirow{2}{*}{ Rata-rata } & \multirow[b]{2}{*}{ Kriteria } \\
\hline & & 1 & 2 & 3 & 4 & 5 & & & \\
\hline 5 & Navigasi & & & & 13 & 14 & 122 & $90,37 \%$ & Sangat Baik \\
\hline 6 & Penggunaan animasi & & & & 10 & 17 & 125 & $92,59 \%$ & Sangat Baik \\
\hline 7 & Interaksi & & & & 11 & 16 & 124 & $91,85 \%$ & Sangat Baik \\
\hline
\end{tabular}

Adapun rangkuman persentase rata-rata hasil penilaian terhadap media pembelajaran interaktif pada pembelajaran Bahasa Indonesia oleh ahli materi, ahli desain pembelajaran, ahli rekayasa perangkat lunak, uji coba perorangan, uji coba kelompok kecil dan uji coba lapangan dapat dilihat pada Tabel 8.

Tabel 8. Rangkuman Persentase Rata-Rata Hasil Penilaian Terhadap Media Pembelajaran Interaktif pada pembelajaran Bahasa Indonesia

\begin{tabular}{|l|l|c|c|}
\hline No & \multicolumn{1}{|c|}{ Responden } & Persentase Rata-rata & Kriteria \\
\hline 1 & Ahli materi & $83,25 \%$ & Sangat Baik \\
\hline 2 & Ahli desain pembelajaran & $89,83 \%$ & Sangat Baik \\
\hline 3 & Ahli rekayasa perangkat lunak & $89,19 \%$ & Sangat Baik \\
\hline 4 & Siswa pada uji coba perorangan & $91,55 \%$ & Sangat Baik \\
\hline 5 & Siswa pada uji coba kelompok kecil & $90,72 \%$ & Sangat Baik \\
\hline 6 & Siswa pada uji coba lapangan & $93,04 \%$ & Sangat Baik \\
\hline & Rata-Rata & $\mathbf{8 9 , 5 9 \%}$ & Sangat Baik \\
\hline
\end{tabular}

\section{Pengujian Hipotesis}

Hipotesis yang diajukan pada penelitian ini adalah terdapat perbedaan yang signifikan antara hasil belajar siswa yang dibelajarkan dengan penggunaan media pembelajaran interaktif dan hasil belajar siswa yang dibelajarkan dengan penggunaan media pembelajaran Power Point. Rumus yang digunakan untuk uji hipotesis adalah uji-t.

\section{1) Pretest}

Hasil belajar siswa yang dibelajarkan dengan dengan penggunaan media pembelajaran interaktif didapat mean 52,30, varians 12,51 dan dengan penggunaan media pembelajaran power point didapat mean 53,00, varians 14,40, Maka dapat diketahui varians gabungan 13,45 dan standar deviasi gabungan 3,67, Maka dapat diketahui $t_{\text {hitung }}=0,60$, Dengan membandingkan $t_{\text {hitung }}$ dengan $t_{\text {tabel }}$ diperoleh $\mathrm{t}_{\text {hitung }}<\mathrm{t}_{\text {tabel }}$ atau $0,60<1,69$. Jadi dapat disimpulkan tidak terdapat perbedaan hasil belajar Bahasa Indonesia antara siswa kelompok eksperimen dengan kelompok kontrol.

\section{2) Posttest}

Hasil belajar siswa yang dibelajarkan dengan dengan penggunaan media pembelajaran interaktif didapat mean 87,70, varians 24,16 dan dengan penggunaan media pembelajaran power point didapat mean 53,00, varians 14,40, Maka dapat diketahui varians gabungan 69,90 dan standar deviasi gabungan
22,84, Maka dapat diketahui $\mathrm{t}_{\text {hitung }}=11,61$, Dengan membandingkan $t_{\text {hitung }}$ dengan $t_{\text {tabel }}$ diperoleh $t_{\text {hitung }}>t_{\text {tabel }}$ atau 11,61 $>1,69$. Jadi dapat disimpulkan terdapat perbedaan hasil belajar Bahasa Indonesia antara siswa kelompok eksperimen dengan kelompok kontrol. Hal ini berarti hasil belajar siswa yang dibelajarkan dengan dengan penggunaan media pembelajaran interaktif lebih tinggi dari hasil belajar siswa yang dibelajarkan dengan peggunaan media pembelajaran Power Point, Efektifitas penggunaan media Interaktif sebesar $87,70 \%$. Nilai keefektifan media pembelajaran interaktif ini lebih tinggi dari nilai keefektifan media pembelajaran Power Point yaitu sebesar $69,90 \%$

\section{Pembahasan}

Produk pengembangan media pembelajaran interaktif pada Pembelajaran Bahasa Indonesia merupakan materi pembelajaran Bahasa Indonesia yang telah dikembangkan dengan memperhatikan aspek pembelajaran dan media sebagai prinsip desain pesan pembelajaran. Penelitan pengembangan produk yang dilakukan ini diarahkan untuk menghasilkan suatu produk berupa media pembelajaran interaktif pada pembelajaran Bahasa Indonesia untuk siswa SMA Kelas XI yang digunakan untuk meningkatkan proses pembelajaran maupun kompetensi siswa. Karena itu dalam prosesnya penelitian ini 
dilakukan dengan diawali studi pendahuluan, kemudian mendesain media pembelajaran, melakukan validasi produk dan melakukan revisi dan penyempurnaan berdasarkan analisis data validasi dari ahli materi, ahli desain pembelajaran dan ahli rekayasa perangkat lunak yang dilanjutkan dengan uji coba perorangan, uji coba kelompok kecil, dan uji coba lapangan sehingga dihasilkan media pembelajaran yang layak digunakan sesuai dengan karakteristik bidang studi dan siswa sebagai pengguna.

Aspek yang direvisi dan disempurnakan berdasarkan analisis data dan uji coba serta masukan dari ahli materi, ahli desain pembelajaran, ahli rekayasa perangkat lunak dan siswa selaku pengguna media pembelajaran interaktif ini, bertujuan untuk menggali beberapa aspek yang lazim dalam proses pengembangan suatu produk. Variabel-variabel media pembelajaran memiliki nilai rata-rata sangat baik. Adapun variabel media pembelajaran yang dinilai meliputi kelayakan isi, penyajian, kebahasaan, pemprograman, dan kegrafikan.

Manfaat yang diperoleh dari penggunaan media pembelajaran interaktif adalah konsep yang disajikan mudah dipelajari, dipahami dan sistematis. Media pembelajaran interaktif memberi kesempatan pada siswa untuk belajar sesuai dengan kecepatan masingmasing, belajar lebih cepat, mandiri dan tidak menimbulkan kebosanan karena dilengkapi dengan gambar-gambar dan animasi serta soal latihan yang bervariasi. Adanya pengulangan yang harus dilakukan saat jawaban salah menjadikan siswa lebih memahami materi. Media pembelajaran interaktif ini juga dapat digunakan sebagai alternatif media pembelajaran secara klasikal maupun individual.

Hasil pengolahan data penelitian yang telah dilakukan, terdapat perbedaan hasil belajar Bahasa Indonesia antara siswa yang dibelajarkan dengan menggunakan media pembelajaran interaktif dan siswa yang dibelajarkan dengan menggunakan media pembelajaran Power Point yaitu rata-rata hasil belajar Bahasa Indonesia siswa yang dibelajarkan dengan menggunakan media pembelajaran interaktif lebih tinggi dibandingkan dengan siswa yang dibelajarkan dengan menggunakan media pembelajaran Power Point. Hal ini dapat dilihat dari hasil nilai rata-rata Bahasa Indonesia siswa yang yang diajar dengan media pembelajaran interaktif yaitu sebesar $87,70 \quad(87,70 \%)$, sedangkan hasil nilai rata-rata Bahasa Indonesia siswa yang yang diajar dengan media pembelajaran interaktif Power Point sebesar $69,90(69,90 \%)$. Dari data ini membuktikan bahwa penggunaan media pembelajaran interaktif lebih baik dalam meningkatkan pengetahuan siswa dalam pembelajaran Bahasa Indonesia daripada penggunaan media pembelajaran interaktif Power Point.

Berdarkan hasil penelitian yang relevan oleh Pujiadi (2010:1) yang berjudul pengembangan game edukasi untuk media bantu pembelajaran drill and practice sebagai persiapan siswa menghadapi ujian nasional matematika SMA, menyatakan bahwa penggunaan media games pembelajaran dalam uji coba lapangan mampu meningkatkan pemahaman materi dan sudah memenuhi kategori sangat baik dan layak digunakan dalam pembelajaran matematika SMA. Hal ini membuktikan bahwa pengembangan media pembelajaran perlu selalu dikembangkan untuk meningkatkan kualitas pembelajaran di sekolah.

Penggunaan media pembelajaran interaktif dalam pembelajaran Bahasa Indonesia memungkinkan siswa untuk berinteraksi langsung dan melakukan kontrol langsung pada sumber informasi, sehingga siswa dapat mengidentifikasi ciri-ciri kalimat efektif dan menggunakan kalimat efektif dalam menulis kalimat maupun wacana yang telah disediakan dalam media pembelajaran interaktif. Siswa juga dapat mengerjakan soal-soal latihan yang telah dilengkapi dengan balikan dan pembahasan sehingga siswa dapat mengetahui kesalahan yang telah dilakukan dalam mengerjakan soal latihan tersebut. Media pembelajaran interaktif juga dilengkapi dengan rangkuman yang dapat membantu siswa memperoleh ringkasan materi pelajaran yang dipaparkan.

Pembelajaran dengan media interaktif juga memungkinkan guru bebas melakukan interaksi dengan siswa sehingga pembelajaran tersebut bersifat interaktif yang membuat pembelajaran terfokus pada informasi yang sedang dipelajari. Hal ini berbeda dengan pembelajaran menggunakan media pembelajaran Power Point, siswa tidak berinteraksi langsung pada sumber informasi dan pembelajaran didominasi oleh guru yang menyajikan informasi secara linier atau satu arah. Hal ini terjadi karena pada media pembelajaran Power Point siswa mendapatkan 
sumber informasi hanya dari guru dan materimateri yang ada pada buku teks tanpa bisa memperoleh balikan dari soal-soal latihan yang dikerjakan. Pembelajaran dengan menggunakan media pembelajaran Power Point menempatkan guru sebagai pelaku yang aktif, sementara siswa relatif pasif hanya menerima dan mengikuti apa yang disampaikan guru. Guru menyampaikan materi secara terstruktur dengan harapan materi pelajaran yang disampaikan dapat dikuasai dengan baik dengan terfokus kepada kemampuan akademik.

Walaupun dalam penelitian diperoleh data bahwa hasil belajar Bahasa Indonesia siswa lebih tinggi jika dibelajarkan dengan media pembelajaran interaktif daripada hasil pembelajaran Bahasa Indonesia siswa yang dibelajarkan dengan media pembelajaran Power Point, namun dalam pelaksanaannya kedua media pembelajaran ini telah mampu meningkatkan pemahaman dan hasil belajar Bahasa Indonesia siswa. Keefektifan penggunaan media pembelajaran interaktif adalah sebesar 87,70\% dan Power Point sebesar $69,90 \%$.

\section{PENUTUP \\ Simpulan}

Hasil validasi dari ahli materi terhadap media pembelajaran interaktif pada pembelajaran Bahasa Indonesia yang telah dikembangkan menunjukkan bahwa; (1) kualitas materi pembelajaran dinilai sangat baik, (2) kualitas strategi pembelajaran dinilai sangat baik, (3) kualitas sistem penyampaian pembelajaran dinilai sangat baik. Dengan demikian media game pembelajaran yang dikembangkan secara keseluruhan termasuk dalam kategori "Sangat Baik".

Hasil validasi dari ahli desain pembelajaran terhadap media pembelajaran interaktif pada pembelajaran yang dikembangkan menunjukkan bahwa; (1) kualitas desain informasi aspek kelayakan isi dinilai sangat baik, (2) kualitas desain informasi aspek penyajian dinilai sangat baik, (3) kualitas desain interaksi dinilai baik, (4) kualitas desain presentasi dinilai sangat baik, (5) kualitas desain informasi aspek kegrafikan dinilai baik. Berdasarkan hasil validasi tersebut disimpulkan bahwa media game pembelajaran pada pembelajaran Bahasa Indonesia yang dikembangkan termasuk dalam kriteria sangat baik sehingga dapat diterima dan layak digunakan dalam proses pembelajaran.
Hasil validasi dari ahli rekayasa perangkat lunak terhadap media pembelajaran interaktif pada pembelajaran Bahasa Indonesia yang dikembangkan dinyatakan bahwa; (1) kualitas teknis/tampilan dinilai sangat baik, (2) pemprograman dinilai sangat baik. Dengan demikian media pembelajaran interaktif yang dikembangkan secara keseluruhan termasuk dalam kriteria sangat baik.

Menurut tanggapan siswa pada uji coba perorangan dinyatakan bahwa media game pembelajaran yang dikembangkan termasuk kategori sangat baik. Menurut tanggapan siswa pada uji coba kelompok kecil dinyatakan bahwa media game pembelajaran yang dikembangkan termasuk kategori sangat baik. Menurut tanggapan siswa pada uji coba lapangan dinyatakan bahwa media pembelajaran interaktif yang dikembangkan termasuk kategori sangat baik. Media pembelajaran yang dikembangkan peneliti layak untuk digunakan sebagai media pembelajaran Bahasa Indonesia untuk siswa, karena memiliki nilai rata-rata yang lebih tinggi dari nilai median skala Likert.

Terhadap penggunaan media pembelajaran interaktif pada tes hasil belajar siswa menunjukkan bahwa hasil belajar siswa yang dibelajarkan dengan menggunakan media pembelajaran interaktif (kelas eksperimen) lebih tinggi dari hasil belajar siswa yang dibelajarkan dengan menggunakan media pembelajaran power point (kelas kontrol). Media game pembelajaran memiliki keefektifan lebih tinggi dari keefektifan media pembelajaran power point.

\section{Saran}

Berdasarkan hasil temuan yang telah diuraikan pada simpulan serta implikasi hasil penelitian, berikut ini diajukan beberapa saran yaitu:

1. Pembelajaran selama ini masih menggunakan media power point maka disarankan kepada guru agar menggunakan media game pembelajaran sehingga mampu memberikan umpan balik yang baik kepada siswa.

2. Selain itu disarankan kepada guru agar memberi motivasi kepada siswa untuk belajar mandiri dengan menggunakan media pembelajaran interaktif, karena siswa akan mendapatkan informasi yang mereka inginkan melalui media pembelajaran interaktif ini dan mereka 
juga tidak perlu tergantung pada kehadiran guru dalam upaya meningkatkan hasil belajarnya.

\section{DAFTAR PUSTAKA}

Anderson, dkk. 2001. A Taxonomy For Learning, Teacher \&Assessing. New York. Longman,Inc.

AECT. 1977. Definisi Teknologi Pendidikan (satuan tugas definisi \& terminologi AECT). Jakarta: Rajawali.

Arikunto, S. 2009. Dasar-Dasar Evaluasi Pendidikan, ediasi Revisi Jakarta : Bumi Aksara.

Arsyad, A. 2010. Media pembelajaran. Jakarta : Raja Grafindo Persada.

BNSP. (2006). Panduan Penusunan Kurikulum Tingkat Satuan Pendidikan Jenjang Pendidikan Dasar dan Menengah. Jakarta: Tidak diterbitkan

Borg, W. \&V Gall, M.D. 1983. Educational Research. An Introduction ( ${ }^{\text {nd }}$ ed). New York \& London: Longman.

Cheng, G. 2009. Using game making pedagogy to facilitate student learning of interactive multimedia. Australia : Australasian Journal of Educational Technology

Danim, Sudarwan. 2010. Media Komunikasi pendidikan. Jakarta : Bumi Aksara

Dick, W. dan Carey, L. 2005. The Systematic Design of Instruction. United States of America: Scott Foresman and Company

Djiwandono, Soenardi. 2008. Tes Bahasa. Jakarta : Indeks

Emzir. 2012. Metodologi Penelitian Pendidikan.Jakarta : Rajagrafindo Persada

Finoza, Lamuddin. 2010. Komposisi Bahasa Indonesia. Jakarta: Diksi Insan Mulia.

Gredler, Margaret E. Bell. 1991. Belajar dan Membelajarkan. Jakarta: Rajawali Perss

Hamid, K.Abdul. 2009. Teori Belajar dan Pembelajaran. Bandung : Alfa beta

Heinich, Robert, et. Al. 1996 Instructional Media and Technologies for Learning $\left(5^{\text {th }} e d\right)$. New Jersey : A Simon \& Schuster Company Engelewood Cliffs.

Ibrahim. 2008. Prinsip-Prinsip Pembelajaran Bahasa Indonesia. Makasar : Lentera Pendidikan

Keraf, Gorys. 1984. Komposisi. Flores : Nusa Indah
Kusumaningsih, Dewi, dkk. 2013. Terampil Berbahasa Indonesia. Yogyakarta : Andi Offset

Miarso, Yusufhadi. 2009. Menyemai Benih Teknologi Pendidikan (Ed. 1) Cet. Ke-4. Jakarta: Kencana

Pamungkas, Sri. 2012. Terampil Berbahasa Indonesia. Yogyakarta : Andi Offset

Purwanto, Ngalim. 2009. Prinsip-Prinsip dan Teknik Evaluasi Pengajaran Cet. Ke-15. Bandung: Remaja Rosdakarya

Reigeluth, C.M. 1983. Instructional Design Theories and Model. London: Lawrence Erlbaum Associates Publisher

Richey, R. 1986. The Theoretical and Conceptual Bases of Instructional Design. New York. Nichols Publishing Company

Rusman, dkk. 2012. Pembelajaran berbasis teknologi dan informasi dan komunikasi. Jakarta : Rajawali.

Sadiman, A. dkk. 2003. Media Pendidikan, Pengertian, Pengembangan dan Pemanfaatannya . Jakarta : Pustekkom Dikbud.

Sagala, S. 2011. Konsep dan Makna Pembelajaran. Bandung : Alfa beta

Siagian, S, Lingin.(2012) Jurnal Teknologi Pendidikan. Pengembangan Media Pembelajaran Interaktif pada Mata Pelajaran Geografi.

Smaldino, E. S., dkk. 2008. Instrucional Technology and Media For Learning. New Jersey: Upper Saddle River.

Sudjana. 2005. Metoda Statistika (Ed. Ke-6) Cet. Ke-3. Bandung: Tarsito Sinar Baru Offset.

Sumiati. 2008. Metode Pembelajaran. Bandung. Wacana Prima

Sudijono, Anas. 2008. Pengantar Statistik Pendidikan. Jakarta. Raja Grafindo Persada

Sugiyono. 2008. Metode Penelitian Kuantitatif, Kualitatif dan $R \quad \& \quad D$ Cet. $\mathrm{Ke}-4$. Bandung. Alfabeta

Surya, Mohammad. 2003. Psikologi Pembelajaran dan Pengajaran. Jakarta: Pusataka Bani Quraisy

Taufina, 2009. Authentic Assesment Dalam Pembelajaran Bahasa Indonesia Di Kelas Rendah SD.Padang : http://ejournal.unp.ac.id/index.php/pedag ogi 
Warsita, B. 2002. Teknologi Pembelajaran Landasan \& Aplikasinya. Jakarta: Rineka Cipta

Wahana Komputer. Visual Basic 2010 Programing. Yogyakarta : Andi

Wiyanto, Asul. 2012. Kitab Bahasa Indonesia. Yogyakarta: Jogja Bnagkit Publisher
Zaman, dkk. 2012. Pengembangan Multimedia Pembelajaran Interaktif Menggunakan Macromedia Flash Professional pada Pembelajaran Fisika. Indonesian Jornal Of Curriculum and Educational Technology Studies. Jurnal. 1(1)1 